\title{
Introduction
}

\author{
Beth White, Thomas Knowles*
}

\section{J. G. Ballard and Making: An Experiment in Collaborative Practice}

https://doi.org/10.1515/culture-2019-0051

Received September 27, 2019; accepted

\section{Outline of project}

"J. G. Ballard and Making" was an eight-week collaborative project that ran in the second semester of 2017 at Birmingham City University. It brought together students and lecturers from the schools of English and Fashion \& Textiles with the open brief of responding creatively to Ballard's collection of short stories Vermilion Sands (1971). The students collaborated on a series of creative responses to Ballard's work including collage images and sculptures that they presented at "J. G. Ballard Day" (JGB Day) in June 2017. The students also designed and printed a programme to showcase their work and to introduce the conference speakers. In this introductory essay, we explore the concept of making in some of Ballard's key texts; we sketch some of the pedagogical methods and techniques employed on the project, such as the exquisite corpse; we discuss some of the challenges and rewards encountered in responding creatively to Vermilion Sands; and finally introduce the essays that make up this collection. Throughout this essay, and in-between the articles that follow, you will find images of the collages, sculptures and designs that the students produced for the project.

\section{Why J. G. Ballard?}

The works of the post-war British author J. G. Ballard might seem an odd fulcrum for a collaborative project; the erstwhile science fiction (sf) writer and literary provocateur famously populates his works with eccentrics and loners, Byronic heroes, decadents, dreamers, and false prophets. Alienation and an incapacity for or failure of empathy - which Ballard calls variously 'the death of affect' or, in the Vermilion Sands collection, 'beach fatigue' - are the hallmarks of such figures, and his fictional worlds might fairly be described as displaying ambivalence towards human agency. But Ballard's fictions interrogate and perpetuate elements of the avant-garde from Romanticism, through decadence, the figure of the flâneur, aestheticism, symbolism, futurism, surrealism, psychogeography, posthumanism and more, making them enormously rich sourcebooks for creative inspiration. Even more important for our project, though, was the fact that Ballard's characters make strange things. The things that they make are frequently surreal; made up of discarded or seemingly useless objects combined in counter-intuitive ways, they offer oblique windows onto the conditions of modernity. It is possible to see these weird creations as epiphenomena of disturbed minds-as futile and dispiriting as the wall that Kafka's K builds in The Castle (1926). While there is certainly an element of the Kafkaesque in Ballard's fiction, it is also possible to read a revelatory and revolutionary potential in his characters' efforts to understand and concretize abstract and conceptual problems through the physical manipulation and arrangement of objects. Such repurposing invokes the

\footnotetext{
*Corresponding author: Thomas Knowles, Coventry University, Coventry, UNITED KINGDOM, E-mail: Thomas.Knowles@coventry.ac.uk

Beth White, Birmingham City Univerity
} 
radical gestures of artist collectives such as the Letterist International and the Situationist International; they might be read as détournements that hijack the slogans and images of consumer capitalism in order to undermine and critique. Below we give some examples of such making in Ballard's short stories and novels, before turning to the Vermilion Sands collection which powered our project.

\section{Making in Ballard's novels and short stories}

The 1960 short story "The Voices of Time” sees a dwindling human population coming to terms with twin entropies: that of the human genome, which has exhausted its capacity for evolutionary change, and the heat death of the universe, in which the end of our solar system is merely the latest in an endless accumulation of expired extra-terrestrial civilisations. An ever-increasing need for sleep, leading to perpetual coma, is afflicting large numbers of people. Meanwhile, Kaldren has had his need for sleep surgically removed in an experiment to find a cure for the malaise, but his inability to dream has deleterious effects on the young man. Kaldren keeps himself busy anticipating the end of the universe, and scheming to build a new world for himself out of what he calls his "Terminal Documents". These include the Association Tests of the Nuremberg Twelve, Beethoven's blind quartets, the complete works of Freud, and an automatic novel. Kaldren arranges these objects in his geometrically and architecturally impossible home, where he watches a ticker-tape report of the countdown to the end of the universe. It will not come during his lifetime, but so altered is Kaldren's perception of time that he is able to wait patiently for this far off event as though it were his own personal apocalypse. Kaldren is not the only 'maker' in this story. The scientists responsible for removing his sleep have also been bombarding plant, animal and insect life with radiation in an attempt to reinvigorate their genes. One such creature is a blind spider whose web, "[C]onsists of nervous tissue. The ladders form[ing] an external neural plexus, an inflatable brain as it were, that he can pump to whatever size the situation calls for" (Ballard, 2009 176). This might be a scene of horror-Frankenstein's laboratory extended to include all of creation, but the horror is tempered by wonder and lyricism, such as in the description of a sunflower that can see time, and a sea anemone that can hear primary colours. Finally, we have the strange case of the protagonist, Powers' mandala, which he laboriously constructs in concrete on the target bull of an abandoned weapons range, before reclining within its sphere to await time's end. This is, on the one hand, very much like K's aforementioned wall in The Castle, but the pantheistic movement that runs through the Powers' experience of deep time generates an altogether different charge to this ostensibly meaningless act of making.

In the 1982 short story "Memories of the Space Age”, Mallory finds himself compelled to travel towards, rather than away from, a mysterious disaster area-a signature Ballard move. The weird disaster has left swathes of the population suffering from a degenerative sleeping sickness that progresses towards a trancelike state in which time stands still. The cause seems obliquely related to the now-abandoned US space program, and its epicentre is the rusting gantries and overgrown launch platforms of Cape Kennedy. Mallory carries with him an eclectic collection of objects that includes,

The tape machine on which he recorded his steady decline; an album of nude Polaroid poses of a woman doctor he had known in Vancouver; his Gray's Anatomy from his student days, a unique work of fiction, pages still stained with formalin from the dissecting-room cadavers; a paperback selection of Muybridge's stop-frame photographs; and a psychoanalytic study of Simon Magus. ${ }^{1}$ (Ballard, 2009 1040)

Mallory refers to this collection of objects as "now almost meaningless", but the peculiar resonances of each of them with elements of the story, as well as with elements of Ballard's biography and interests, in fact render them highly meaningful. One could view them as sequencing codes for a reconstruction of this and perhaps a number of other Ballard stories. Similarly, the narrative is broken into numbered

1 The Simon Magus of the Bible was a first-century AD Samaritan religious figure and magician who converted to Christianity and later quarrelled with the apostle, Peter. Other texts have him as the founder of Gnosticism, or appearing in versions of the Helen (of Troy) myth. His powers of flight and other sorcery are resonant here, as is the Gnostic belief of a spiritual realm beyond the fallen material realm. The invocation of Simon Magus and psychoanalysis also calls to mind the incantatory power of language and the resonance of ritual and cathected objects. 
sections that do not necessarily appear in chronological order, inviting processes of reconfiguration and reinterpretation-a readerly 'making' of the text.

In the obliquely connected story "Myths of the Near Future" (1982), Sheppard calls a similarly eclectic collection of objects his 'survival kit'. He hopes that 'a framed reproduction of Magritte's The March of Summer, a portable video cassette projector, two tins of soup, a well-thumbed set of six Kamera Klassic magazines, a clutch of cassettes labelled Elaine/Shower Stall I-XXV, and a paperback selection of Marey's Chronograms' (Ballard, 2009 1068), will help him to find his dead wife.

The 1976 novella "The Ultimate City" is set in a post-fossil fuel world, sometime after the collapse of capitalist and consumer society. Through its opposition of a technologically-advanced pastoral utopia, with an atavistic drive to rediscover the violence and energy of the oil-driven technologies of the twentieth century, "The Ultimate City" revels in the aesthtic possibilities that industrial and consumer waste afford.

Terrace upon terrace of climbing plants hung from the chassis of the cars, brilliant flowers bloomed in the windows and wheel-wells. The golden bells of forsythia trailed from the windows of grand limousines a hundred feet in the air, the white mist of mile-a-minute vines hovered like steam above the radiator grilles and exhaust pipes. (Ballard, 2009 898)

Here, the making is decidedly industrial and is contrasted with the bespoke craftsmanship of the Garden City, and yet it is interwoven with the verdure of a resurgent natural world. The narrator refers to this collaboration between the natural and the built environments as "strange", and it is the power of such juxtapositions that engenders the dreamlike quality to the post-industrial New York of the novella. The 1970s saw a turning point in Ballard's friend and collaborator Eduard Paolozzi’s work, a move away from the crafted sculpture of his earlier pieces in plaster and bronze and towards aluminium, which he produced in collaboration with engineers employing industrial processes. Stories such as "Memories of the Space Age" offer a route back, through evermore archaic technologies, to the dream impulse behind the original making-in the case of that story, it is the dream of flight whose catastrophic eschatological endpoint is the U. S. space programme. "The Ultimate City", however, imagines a future primitivism in which the technology of the twentieth century is fetishized for its inefficiency and disposability, its mass-produced anonymity, and because of the intoxicating aggression and violence that underpins its making and use.

There are many more examples of the recombination and juxtaposition of objects in Ballard's works, and they share the function of stimulating an imaginative way out of an unacceptable reality-be it the death of a loved one, capitalist consumerism and its media landscapes, ecological collapse, the failure or absence of empathy, or creative malaise. Such ennui fuels the experimentation of the various art collectives of Ballard's Vermilion Sands stories, and it is to those that we turn now.

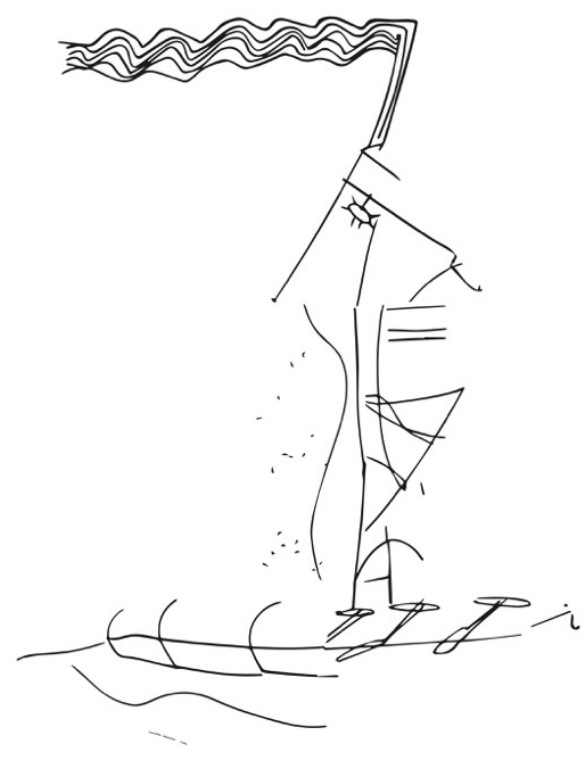

Figure 1. Cry Hope, Cry Fury 
So much for Ballard's lone makers, but what about the artist collectives that populate the beach resorts of the Vermilion Sands stories-how is their making collaborative and to what effect? For our Fashion students, "Say Goodbye to the Wind" (1970)-with its lurid, bio-engineered, semi-sentient, and murderous clothing-was an obvious touchstone. The collaboration in this narrative is somewhat diffuse, however, and the making that occurs takes place between the landscape and the consumer art objects abandoned to it as waste. The singing flowers and sculptures, discarded by their owners, "run to seed" and return as the techne of an overspill of praxis into the non-human landscape, "Running to seed on the sand reefs of Vermilion Sands, the singing flowers and sculpture formed the unique flora of the landscape, an island ringed by strange sounds" (Ballard, 2009 128). Such objects, which recur throughout the stories of this collection, suggest that poiesis is not confined to the realm of human activity, and that it may be better understood as an ongoing process of becoming in which human beings, other lifeforms, and even objects may intervene and intend. This is something like the distributed agencies of objects in assemblages which Jane Bennett has described in Vibrant Matter (2010 Chapter 2). That the island ringed by strange sounds invokes Shakespeare's The Tempest, of course-"Be not afeard, the isle is full of noises" (Act 3, Scene 2, 1. $119)$-a text that is frequently alluded to and reworked by Ballard in works such as "The Ultimate City", Concrete Island (1974) and The Drought (1964). Shakespeare's Prospero unmakes all of his works and his means of making them in the closing scene of the play, but there seems to be left open the possibility that the winds of creativity will blow once more, instigating a bevy of making. Such reinvigorating wind blows through Concrete Island, "The Ultimate City" and the Vermilion Sands stories. Knowles (2016) has related the work of the wind in the latter to the work of the Aeolian Harp in Romantic literature, but the Prospero/ Ariel dynamic seems equally relevant to the ebb and flow of making that we are here considering.

There is not space here to discuss all of the Vermilion Sands stories, but the poetry makers of "Studio 5, The Stars" are perhaps especially worthy of mention, as are the filmmakers and set designers of "The Screen Game”. The latter begins with a lyrical description of Vermilion Sands, this place outside of timepossible future or unrealised past?--where work and leisure become indistinguishable.

The season had ended, and already the desert had begun to move in again for the summer, drifting against the yellowing shutters of the cigarette kiosks, surrounding the town with immense banks of luminous ash. Along the horizon the flattopped mesas rose into the sky like the painted cones of a volcano jungle. (Ballard, 2001 47)

This is a painted and painterly landscape, and it is the task of the narrator and his fellow artists to paint screens of the desert that will form the backdrop to a movie called Aphrodite 80, an auteur's retelling of the Orpheus myth. The film production soon grounds to a halt, however, and the artists instead play the titular screen game with their painted canvases, attempting to lure out the reclusive denizen of Lagoon Heights. The combination of setting and obscure, ritualized actions is highly reminiscent of the cinema of Ingmar Bergman-the checked floor upon which the screen game is played calling to mind the chessboard of The Seventh Seal (1957), for example. In this story, the stalled making, which turns into dangerous play, is reabsorbed by the noisy flora/fauna of the signing statues, and it is replayed to the friends as they continue to play the screen game, long after the film has been abandoned. This is a landscape that is made and remade by making and unmaking, by decay and what grows out of it. In this sense, the creative spark in "The Screen Game" and the other stories of Vermilion Sands is decadent; blooming bruises and fetishism of injured and leaking bodies may be more familiarly associated with Ballard's The Atrocity Exhibition and Crash, but the decline and ennui of beach fatigue and a desiccated landscape, coloured by wan lyricism, suggest the half-light of Charles Baudelaire's "The Sunset of Romanticism".

"Studio 5, The Stars" riffs on the ramifications of automated making for poetry. In a rebuke to the expressive understanding of making and maker that has arguably held sway since the time of Romanticism, the verse-producing IBM VT machines undo the perceived gaucheness of intention and the lyric 'I'. The machines are defeated in this story by a resurgence of individual and collaborative making which requires the poets to relearn their craft, spurred on by a manifestation of the muse, Aurora Day. Given Ballard's avowed dislike for poetry-he described his mission as prose editor of Ambit as to expunge poetry from its pages (Ballard 2012)-might suggest that this poetic renaissance is an ironic one. Ballard did champion 
some poetry, however, such as that of Jeremy Reed, and his work abounds with allusion and reference to Romantic poets including Blake, Coleridge, Wordsworth and Shelley. ${ }^{22}$ The verse machines might be seen to represent the stagnation of any particular period in a particular style and/or the vogue for a particular type of intentionelsss making. At a time when Concrete Poets were experimenting with machinic production of verse, Ballard was writing about the inevitable kick-back in the form of the rediscovery of the imagination and meaning-making. ${ }^{3}$ Surrendering to obsession and sacrifice are some of the lessons which the poets of "Studio 5, The Stars" have to relearn, and they do this in part through their shared obsession with the mysterious Aurora Day. Ballard's knowing invocation of the muse represents poetry as the adolescent effusions of erotically-fixated men, while nonetheless lyrically celebrating the liberation of the imagination that surrender to such obsession might bring.

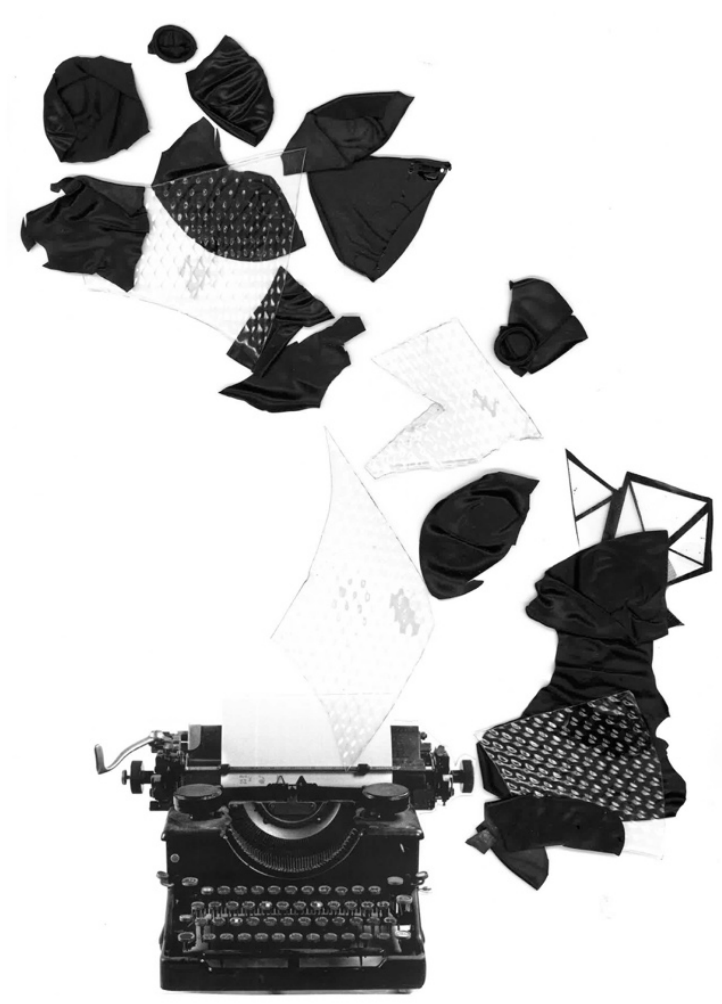

Figure 2. Studio 5 The Stars

\section{Ballard and Collaboration}

As Jeanntte Baxter (2009) has shown, Surrealism and Pop Art were major influences on Ballard; his novels and short stories often reference or feature Surrealist works, and he wrote about the importance of Surrealism in essays like "Time, Memory and Inner Space" (1963) and "The Coming of the Unconscious" (1966). Indeed, many of his fictions seem to take place in landscapes familiar from the canvases of Max Ernst, Salvador Dali or Yves Tanguy. For Ballard, the Surrealists were right not to accept reality as they found it, and to follow their obsessions and neuroses, and he consistently championed the transformative

2 For example, The Crystal World (1966) refers to the Wordsworthian childhood and to Shelley's stain on the whiteness of eternity; The Unlimited Dream Company's (1979) protagonist is called Blake and the novel riffs on the private mythologies of William Blake; and Coleridge's nightmare life in death figure haunts various of Ballard's short stories and novels in the form of pale lamia-like women-many such women appear in the Vermilion Sands stories. See Thomas Knowles, Lyrical Ballards: The Wounded Romanticism of J. G. Ballard, which is forthcoming from Bloomsbury.

3 Ballard had himself experimented with layouts of image and text that communicated through typographic arrangement, as much as content in his Diagram for a New Novel of the 50s. 
power of the imagination. But Ballard was alive, too, to the potential for the imagination to be hijacked by what he called the mana personalities of history-for the recuperation of radical aesthetics by reactionary and neo-fascistic forces in modern society.

Ballard collaborated with artists and filmmakers on a number of occasions, and his collaborations share an inspirational source with some of the canonical theorists of collaborative practice: The 1956 "This is Tomorrow" exhibition at the Whitechapel Gallery in London. The exhibition was a collaboration by artists and architects, who produced immersive science-fictional environments through a blend of emerging and imagined technology, art, and science. The artists and architects behind the exhibition, the Independent Group, included the sculptor and collagist Eduardo Paolozzi, the artist Richard Hamilton, and the Brutalist architects Alison and Peter Smithson. The exhibition had an enormous effect on Ballard's imagination; as Ballard scholars David Pringle and Roger Luckhurst have shown, the stories that take place in the desert resort of Vermilion Sands feature artist collectives producing work that bears striking resemblance to avantgarde exhibitions of the 50s and 60s, such as those at the Institute of Contemporary Art (Pringle 2015; Luckhurst 2016). During this period, Ballard would stage his own exhibition of crashed cars; produce a series of four text collages called Diagram for a New Novel, and take out a series of full-page advertisements in magazines featuring combinations of pornographic imagery-some of which was supplied by Eduardo Paolozzi-and text, gnomically instantiating themes that would be explored in subsequent short stories and novels.

\section{Art movements and Collaboration}

Conscious collaboration is clearly not a new idea and early examples of interdisciplinary practice provide real insights into participatory learning; the aforementioned Independent Group is a highly significant example. The Group, formed of writers, thinkers and creative practitioners, worked across interdisciplinary boundaries and created a radical approach to looking and working with visual culture. David Robbins explains the approach further in his book titled The Independent Group - Post-war Britain and The Aesthetics of Plenty.

The approach was inclusive and respectful, drawing from inspiration as diverse as communication theory, anthropology and non-Aristotelean philosophy. The approach also spanned the entire cultural landscape of post-war Britain and inhabited the spaces between a multitude of concepts, practices and disciplines. (Robbins, D.1990)

Further early examples of collaboration and artistic synergy include the Soviet Constructivist movement who were also in favour of art as a practice for social purpose and actively rejected the idea of autonomous art. The movement found followers across the continent especially in the Dutch artistic movement known as De Stijl. This movement was founded on four key principles, most notably collaborative practice, and brought together a collective of writers, artists and architects for the purpose of universal harmony.

De Stijl stands out because its aspirations were as social as they were aesthetic. By ostensibly removing the individualism of the artist in favour of precision and universal harmonies, the De Stijl group believed they were laying the groundwork for a future utopia. (Alex Bigman 2013)

Today the principles of true collaboration remain the same, to combine the disjointed knowledge of diverse individuals for the purpose of creating original ideas and new work. The Vermilion Sands stories feature similar artist collectives; within the pilot project, students collaborated to create objects and images out of Ballard's fictional world - analysing and critiquing it from within rather than attempting to maintain a critical distance as in a more traditional literary study.

It is important to revisit these earlier models of collaboration and the examples identified within this paper represent a new way of engaging in creativity with a collective society. The early artistic movements including the Soviet Constructivists in the 1920s and the Independent Group in the 1950s provide a blueprint for teaching and learning practices today. Their connectivity as a group and their multi-layer approach to design highlight the continued importance of developing knowledge communities across a variety of 
disciplines.

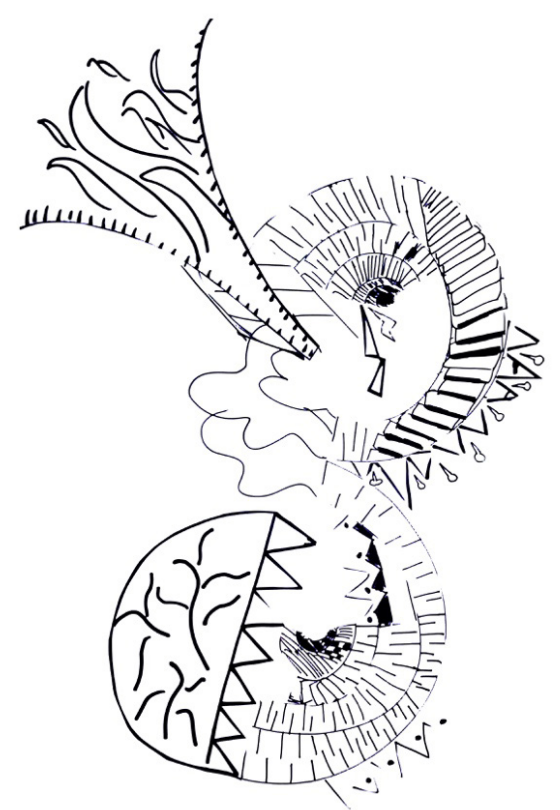

Figure 3. The Screen Game

The term collaborative practice, according to Bruffee (1984), was first coined in an educational context by a group of secondary school teachers and a biologists studying medical education in the1950s and 60 s - note the contemporaneity of the aforementioned Independent Group and the "This is Tomorrow" exhibition. Some of what Bruffee noted as radical in his 1984 survey of the field Collaborative Practice and the 'Conversation of Mankind has no doubt come to seem orthodox: across disciplines we routinely set group activities and provide opportunities for peer review and support.

Kenneth Bruffee also identified collaborative practice as a form of social group work and believes that knowledge is best constructed within knowledge communities. In his 1985 essay titled 'Social Construction, Language, and the Authority of Knowledge' he outlines the implications of a nonfoundational social constructionist understanding of knowledge and acknowledges the potential of social construction as a fertile resource for teachers and scholars. He explains that in cognitive terms the individual is the matrix of all thought and a great idea is often the product exclusively of a single mind, while in contrast, social construction assumes that the matrix of thought is not the individual self but some community of knowledgeable peers and the vernacular language of that community (Bruffee 1985). Social construction, much like the early artistic movements including the Soviet Constructivists, regards terms such as 'intellectual development and production, conceptual frameworks, idea and objectivity as social constructs. They are representative of a particular language that constitutes a particular community of knowledgeable peers much like our students. 


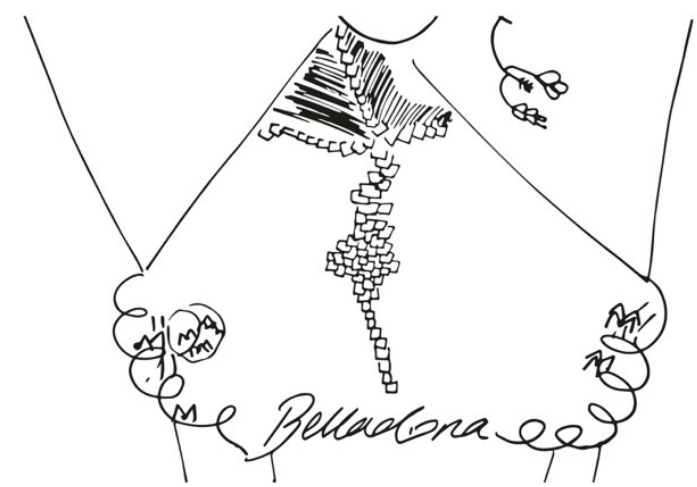

Figure 4. Prima Belladona

\section{Collaborative techniques - Exquisite Corpse.}

The Exquisite Corpse technique has collaboration at its very core, mixing genres, approaches and disciplines. The method follows a simple algorhythm that begins by folding a sheet of paper in four across the horizontal axis. Each participant is in turn asked to make his or her mark on one of the quarters of folded paper. The resulting construction is an amalgamation of random marks using a series of simple asynchronous and contingent operations. This technique acts as a method of collaboration that results from the folding together of multiple ideas. The outcome is a new work independent of any singular contribution.

The Exquisite Corpse game was devised by members of the Surrealist group in the 1930s and represents the infinite possibilities that emerge when creativity is opened up to a crowd. The imperfect and disconnected structures that can be created emphasize the capacity of the crowd to surprise and amuse, in contrast with the holistic aesthetic that usually stems from a single creator.

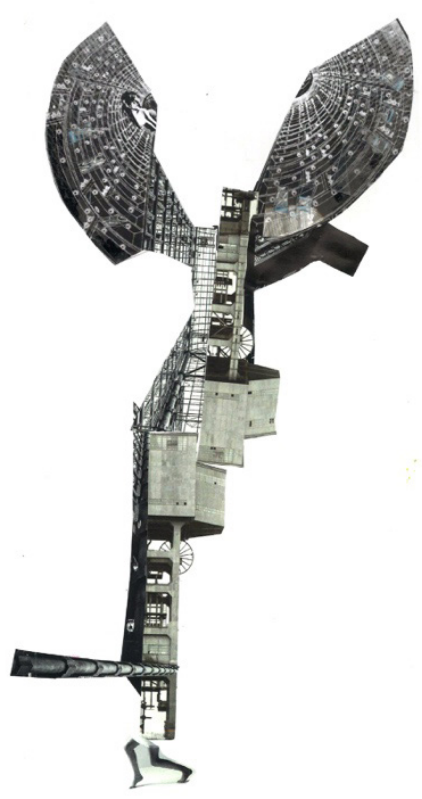

Figure 5. The Thousand Dreams of Stellavista

Our interest in the Exquisite Corpse technique came at a point in the project when students were struggling 
to develop ideas in response to the brief. We also found that there was some resistance to inter-disciplinary practice due to the value placed on individual creativity within our schools and the faculty as a whole. The Cadavre Exquis technique was therefore used as a pedagogical model which resulted in destabilising the frame of the sole learner to accommodate numerous visions. The process enabled the students to broaden the potential for surprising and contrasting ideas to emerge from joint thinking. Vera John Steiner explains the importance of joint thinking further in Creative Collaboration.

Generative ideas emerge from joint thinking, from significant conversations and from sustained, shared struggles to achieve new insight by partners in thought. (Steiner, V, J. 2000)

The students' collage work and drawings inspired by Vermilion Sands included motorcars with word cloud exhausts, singing typewriters, jewelled insects emerging from the pupil of a giant eye, and spiral staircases to nowhere (see images throughout this article). The success of the collage work utilising this openended method allowed the students to not only plan and act jointly, but to also think together, combining independent conceptual themes to create original ideas and outcomes.

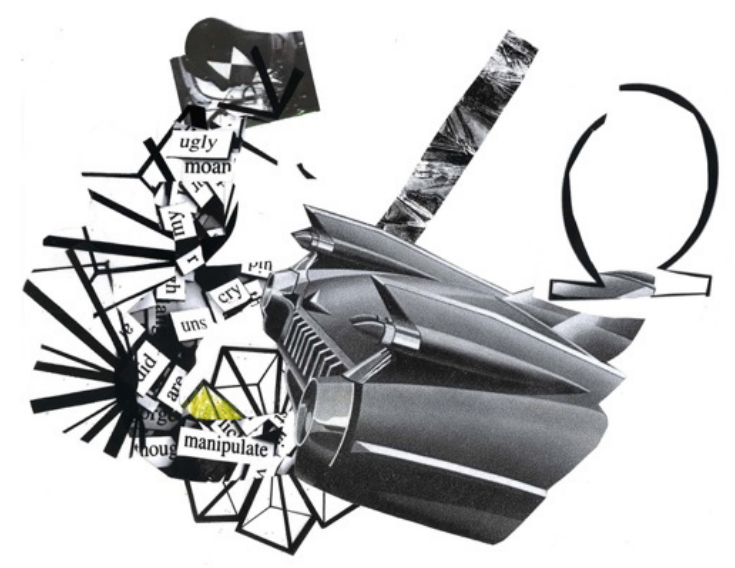

Figure 6. The Cloud Sculptures of Coral D

This practice of building up the work using collage, sketches, found objects and the manipulation of materials draws from the genealogy and the algorithms of the Exquisite Corpse, which is one of the few collaborative exercises to successfully transcend its original time period. If surrealism infuses the strange flora, fauna and landscapes of Red Beach and Vermilion Sands, and if movements like the Independent Group and the exhibitions at the Institute of Contemporary Art are a model for the artist collectives in Ballard's stories, the use of the Surrealist techniques of word association, cut-ups and collage work developed by the students seems entirely appropriate to the reverse engineering of objects from the text. Students raided bins and skips and school clear outs for materials and objects to create a group of sculptures, and such reuse and repurposing chimes with the radical intent of Surrealism and the Soviet Constructivists.

\section{Studio Olafur Eliasson- The Institute of Spacial Experiments}

The revived interest in the exquisite corpse technique and the resurgent interest in the open-ended methodology reflect the penetration of mindsets in contemporary creative culture to uphold the communal over the individual. Ellegood explains her thoughts on collaboration.

Collaborations - whether they incorporate an entire team of participants across the globe or revolve around a longstanding partnership - evaluate and emulate the construction of identity, recognising the numerous social factors that influence subjectivity. (Ellegood, A. 2010) 
Studio Olafur Eliasson is an example of a new breed of pioneering transdisciplinary studios that are leading a revolution by capitalizing on communal ideals. The studio staff at Olafur Eliasson includes fabricators, architects, archivists, filmmakers and art historians. The teams at the studio also collaborate with specialists and cultural practitioners worldwide. As Eliasson explains this further in an interview with Alex Coles, "Collaborative projects not only contextualise aspects of the studio activity but can also generate new ideas to feed back into the studio" (Coles, A 2102). The primary aim of Eliasson's methodology is to challenge the energies of skilled workers in the studio and in doing so Eliasson hopes to intensify the dialogue between them and most importantly produce new work. In an article for Experimental Marathon, Eliasson discusses communication and idea generation.

The form applied to an idea is not only the one that I choose myself, when circulated, every idea picks up dimensions and meaning that I could not have considered and could not have foreseen. Regardless of whether they were productive of my original though or not. (Eliasson, $\mathrm{O}$ and Obrist, U 2009)

In 2009, Eliasson founded an experimental programme in arts education - The Institute of Spatial Experiments - and between 2009 and 2014, Eliasson and his team developed a highly experimental mythological model introducing new approaches to teaching and learning. The purpose of the education model was to help students think and work critically at the same time. With collaborative practice central to the educational experiments unexpected and surprising ideas emerged from within the unique micro ecologies that they had devised. Also part of the success of this art school model was that it readdressed the balance within a design environment to create a creative space where hierarchies are levelled out. Similar to our experiment the central tenant in the methodology was to curate learning situations of uncertain certainty and to act as a catalyst and an activator for further collaborative pilots and experiments.

\section{Conclusion}

The students came to understand difficult literary and theoretical concepts through exploring them in other mediums. They were able to understand and concretize abstract and conceptual problems through the physical manipulation and arrangement of objects. Bruffee (1984) sees collaborative practice as a way of facilitating students' entry into what he calls the 'human conversation'. As teachers, we witnessed our collaborative students enter into the conversation of academic research, and Ballard studies in particular. At the start of the project, group discussions of the Vermilion Sands stories involved a great deal of tutor prompting, and tended to elicit little more than observations of textual elements such as style or atmosphere-and these were not marshalled as concrete examples or evidence for an overarching point or argument. Through the exploration of these texts in multiple mediums and by collaboratively producing artefacts inspired by them, the students attained a level of fluency in these discourses sufficient for them to successfully present, discuss and field questions on their work at an academic conference on Ballard - and this is not something that we would normally expect of second-year undergraduate students.

As a diverse group of individuals from multi-disciplinary backgrounds, the students began to develop a sense of community as the pilot progressed. The students started to construct ideas as a social group and it was clear that their learning began to happen amongst the individuals rather than between them. As the project progressed, the students also learned to depend on each other rather than looking exclusively to the authority of staff. As Bruffee (1985) identified, the language of the community of peers was upheld over the individual self. Throughout the pilot project students worked beyond traditional boundaries and conventional disciplinary areas. Through the co-construction of knowledge students developed new social communities on which they could depend and new ways of engaging in creativity activity. 


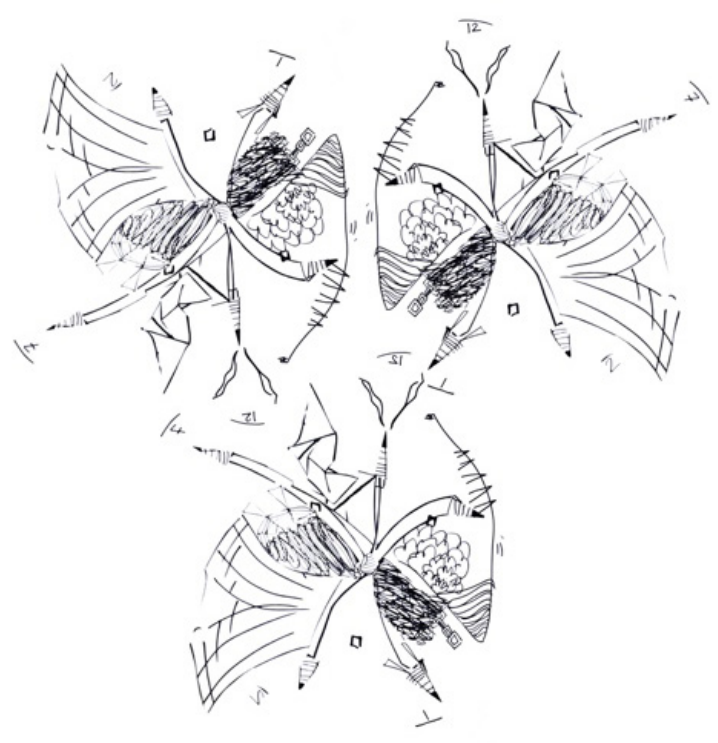

Figure 7. Say Goodbye to the Wind

Students gained ability across the range of disciplines which the project involved, including: teamwork, working to deadlines, conversational and written ability in academic fields, conceptual design skills, and practical skills in working with a range of materials to realise designs. That this also resulted in a new confidence in discussing diverse aspects of their collaboration points to benefits accrued in the process of conceptualizing ideas from different knowledge domains and through different practices. If collaborative practice, following Bruffee, is about what he calls 'conversational proficiency', our students could be said to have improved their fluency in multiple knowledge domains, opening up an array of conversations to which they were newly empowered to contribute.

\section{Essays in this volume}

Dominika Oramus brings out the tension between creativity and destruction in Ballard's works through her reading of unmaking in "The Terminal Beach", The Atrocity Exhibition (1970), Empire of the Sun (1984) and Rushing to Paradise (1994). Oramus' argument is informed by a careful exploration of some of Ballard's nonfiction writings about Hiroshima, Nagasaki and the problems of a post-war peace built upon the "unmaking" of nuclear weaponry. For Oramus, the media's overproduction of images of nuclear mushroom clouds, and the western narrative obsession with nuclear Armageddon, are symptoms of a civilisation in thrall to the death drive, exemplified by the pacific aspect of Ballard's characters as they contemplate the nuclear fusing of mineral and organic worlds. What emerges most powerfully from this reading of the "wastelands created by nuclear explosions"-familiar Ballardian territory-is the ambiguous aesthetics of their representation. These haunted sites offer glimpses of pasts and futures unmade in the blinding light and heat of nuclear Armageddon, but such unmaking might also cleanse the world of its accumulated false meanings in an apocalyptic revelation that is irrevocably fused to the death drive.

Giorgious Crouch caused a minor sensation among attendees at JGB Day 2017. His photographic essay documented his extended dérives around European airports and their zones of influence, revealing a man living the life Ballardian-and this some time before the publication of Simon Sellars' Applied Ballardianism (2018). Like a character from the pages of a Ballard short story or novel, Crouch waxed lyrical on deserted runways and minatory observation towers, sharing with us his obsessions with architectures of motion and eerie silence. At some point after his presentation, Giorgious disappeared-perhaps, we reasoned, eager to begin his next short-haul flight. For some months, we heard nothing. And then the unexpected arrival of his expanded photographic essay for this collection convinced us once again that Crouch was real. It is in 
the finest psychogeographic tradition to make and remake the uses of, and our responses to, landscape by means of the insertion of the presence of the human body where it is neither expected nor welcome. We feel, with Crouch, the thrill of transgression, and we shudder at the indifferent rejection of our fleshly bodies by landscapes coded for violence.

Ciaran Kavanagh's "Categorically Grotesque: Ballard, Bodies and Genre in Crash" offers a fascinating take on Ballard's own making, which in the controversial novel Crash (1973) incorporates "uncannily visible invisible literature", and the "aesthetic and prosaic debris of the marginal" producing an embodied, grotesque erotica. Linking this to the remaking which is performed in the reading moment, and noting the tendency for critics to explain away the gore and erotica of the novel in pursuit of its ostensibly "higher" aims, Kavanagh makes the case for a careful consideration of reader response and authorial intention, while recognising that such approaches are partial and cannot hope to sustainably disambiguate such an overdetermined text.

Tracey Clement's article "Making the Drowned World Manifest" focuses on recent contemporary Australian artworks which were made in direct response to Ballard's 1962 novel, The Drowned World, for a 2015 exhibition she initiated and coordinated titled "Mapping The Drowned World". Using her own artworks as examples, as well as work made by fellow Australian artists Roy Ananda, Jon Cattapan and Janet Tavener, Clement demonstrates that art and Ballard's literature continue to make a great synergistic team: Together they produce more than the sum of their parts.

As we have seen, making in the Vermilion Sands stories and throughout Ballard's oeuvre continues in the face of ennui, the death of affect, beach fatigue, the crushing imposition of the media and concrete landscapes of the post-war world, as well as the prospect of the ultimate unmaking of nuclear Armageddon. In fact, these things are the very stuff of Ballard's and his characters' making. Making in Ballard recombines Romantic, Surrealist and psychoanalytic tropes and methods in a way that foregrounds the importance of play, reuse, and humour. Ballard's texts demand rereading, reinterpretation and reverse-engineering back into the multiple mediums that inspired their composition. In this way they were the perfect hinge for our collaborative project, and the essays in this collection demonstrate their ripeness for further performative, collaborative, elaborative translation.

\section{Works Cited}

Ballard, J. G. The Complete Short Stories. W. W. Norton, 2009.

Ballard, J. G. Vermilion Sands. Vintage, 2001 [1971].

Ballard, J. G. Interview with Thomas Frick in Paris Review \#94, Winter 1984. In Extreme Metaphors, edited by Dan 0’Hara and Simon Sellars. Fourth Estate, 2012.

Baxter, Jeannette. J. G. Ballard's Surrealist Imagination: Spectacular Authorship. Ashgate, 2009.

Bennett, Jane. Vibrant Matter: A Political Ecology of Things. Duke University Press, 2010.

Bigman, A. A brief history of the utopian De Stijl movement. (Online) Available at: https://99designs.co.uk/blog/ creative-inspiration-en-gb/know-your-design-history-the-utopian-de-stijl-movement/(Accessed 20th may 2017)

Bruffee, K. Collaborative Learning and the conversation of Mankind. College English.1984.

Bruffee. K. Social Construction, Language, and the Authority of knowledge: A bibliographical Essay. College English. Vol 48. No 8. 1986

Coles, Alex, The Transdisciplinary Studio. Sternberg Press.2012.

Ellegood, A. The Exquisite Corpse is Alive and Well. Tate Etc. Issue 18. 2010

Knowles, Thomas. "Aeolian Harps in the Desert: Romanticism and Vermilion Sands". In J. G. Ballard: Landscapes of Tomorrow, edited by Richard Brown et al. Brill Rodopi, 2016, pp. 23-39.

Knowles, Thomas. Lyrical Ballards: The Wounded Romanticism ofJ. G. Ballard. Bloomsbury, forthcoming (2020).

Luckhurst, R. “J G Ballard and modern art”. (Online) Available at: https://www.bl.uk/20th-centuryliterature/articles/j-gballard-and-modern-art (Accessed 01 October 2019).

Poggenpohl, S and Kehchi, S. Design Integrations- Research and Collaboration. Bristol. Intellect. 2009.

Pringle, D. “J. G. Ballard Chronology 1955-62“. In Deep Ends 2015, edited by Rick McGrath. Terminal Press, 2015, pp. 12-56.

Robbins, D. The Independent Group: Postwar Britain and The Aesthetics of Plenty, MIT Press.1990.

Steiner, V, J. Creative Collaboration, Oxford University Press.2006.

Sato, P. Design Integrations. Research and Collaboration, Intellect Ltd. 2009.

Schneiderman, D, Kochhar-Lindgren, K, Denlinger, T. The exquisite corpse: chance and collaboration in surrealism's parlour game. University of Nebraska Press.2009.

Shakespeare, William. The Tempest. In RSC William Shakespeare Complete Works, edited by Jonathan Bate and Eric Rasmussen. RSC, 2007, p. 34. 